\title{
The European Court of Human Rights and Domestic Violence: Volodina v. Russia
}

\author{
Ronagh J.A. McQuigg \\ Senior Lecturer, School of Law, Queen's University Belfast, Belfast, UK \\ r.mcquigg@qub.ac.uk
}

\begin{abstract}
This article addresses the highly significant area of the approach adopted by the European Court of Human Rights (ECtHR) to the issue of domestic violence. During the past thirteen years, the Court has firmly established that domestic violence can constitute a violation of the European Convention on Human Rights (ECHR), however the way in which this issue has been contextualised by the ECtHR has varied and evolved, namely in terms of which articles of the ECHR have been held to have been violated in such cases. The Court's recent judgment in Volodina $v$ Russia again raises important questions regarding the conceptualisation of domestic violence by the ECtHR, as discussed in this article.
\end{abstract}

\section{Keywords}

European Court of Human Rights - domestic violence - Volodina v Russia - torture - inhuman or degrading treatment

\section{Introduction}

With the recent case of Volodina v. Russia, ${ }^{1}$ the European Court of Human Rights (ECtHR) has again added to its ever-expanding jurisprudence on the issue of domestic violence. Since its judgment in Kontrova v. Slovakia in 2007, ${ }^{2}$ the Court has made it clear that domestic violence can constitute a violation

\footnotetext{
1 [2019] ECHR 539.
}

2 [2007] ECHR 419. 
of the European Convention on Human Rights 195 O (ECHR). ${ }^{3}$ However the way in which domestic violence has been contextualised in the judgments of the ECtHR has varied and evolved over the past thirteen years, namely in terms of which articles of the ECHR have been held to have been violated in such cases. The Court's recent judgment in Volodina v. Russia again raises issues regarding the conceptualisation of domestic violence by the ECtHR, as will be discussed in this article.

\section{2 The Facts of Volodina v Russia}

In November 2014 the applicant commenced a relationship with a man referred to in the judgment of the ECtHR as S., and they began living together in Ulyanovsk. In May 2015 the applicant moved out, whereupon S. threatened to kill both the applicant and her son if she refused to return to live with him. In January 2016 the applicant complained to the police that S. had broken the windscreen of her car, however the police did not institute criminal proceedings as S. replaced the damaged windscreen. The applicant then moved to Moscow. She published her curriculum vitae on a number of job-hunting websites and a person referred to in the judgment as D. invited her to what she believed was a job interview. D. collected the applicant in his car, however S. then appeared from the back of the car and brought the applicant back to Ulyanovsk after taking her mobile phone and personal effects. Following their return to Ulyanovsk, S. punched the applicant in the stomach and face. She was taken to hospital and it was established that she was nine weeks pregnant, but that there was a risk of a miscarriage. The applicant underwent an abortion. She reported the violence to the police, however later withdrew her complaints and no further action was taken.

In May 2016 S. punched the applicant in the stomach, pushed her to the ground and began to choke her. The applicant complained to the police,

3 See for example, Bevacqua and S. v. Bulgaria [2008] ECHR 498; Opuz v. Turkey (2010) 5 O E HRR 28; E.S. and Others v. Slovakia, [2009] ECHR 1282; A v. Croatia [2010] ECHR 1506; Hajduova v. Slovakia [2010] ECHR 1908; Kalucza v. Hungary [2012] ECHR 756; Valiuliene v. Lithuania [2013] ECHR 24O; Eremia and Others v. Republic of Moldova (2014) 58 E HR R 2; B. v. Republic of Moldova [2013] ECHR 684; Mudric v. Republic of Moldova [2013] ECHR 685; N.A. v. Republic of Moldova [2013] ECHR 86o; T.M. and C.M. v. Republic of Moldova [2014] ECHR 81; M.G. v. Turkey [2016] ECHR 295; Balsan v. Romania [2017] EC HR 468; Talpis v. Italy [2017] ECHR 224. For an overview of the jurisprudence of the ECtHR on domestic violence, see R McQuigg, The Istanbul Convention, Domestic Violence and Human Rights (Routledge, 2017) 6o-67. 
however no criminal proceedings were instigated as the police were of the view that no prosecutable offence had been committed. Later that month the applicant returned to Moscow in an attempt to hide from S., however in July 2016 he found and attacked her. Neighbours who had witnessed the attack called the police, and the applicant lodged a criminal complain against S., reporting that he had been violent and had threatened to kill her. In August 2016 S. sent a text message to the applicant, stating that he had damaged the braking system of her car. The applicant called the police, and an officer arrived and took stock of the extent of the damage. However again the police declined to prosecute $S$.

In September 2016 the applicant discovered an electronic device in the lining of her bag, which she believed was a GPS tracking device placed there by S. She reported her concerns to an Investigative Committee in Moscow, which forwarded the report to the police, however no inquiry was initiated. In early 2018 , S. placed the applicant's private photographs on a social network without her consent, and in March 2018 the police initiated a criminal investigation for invasion of personal privacy.

On 12 March 2018 the applicant reported to the police that she had received threatening calls from $\mathrm{S}$. the previous night and that he had been in front of her home earlier that day. On 21 March the police declined to commence a criminal investigation as they believed that there had been no danger of S. carrying out the threat to kill the applicant, due to the fact that she had remained in her flat and S. had stayed in his car. Also on 21 March, the applicant called a taxi in order to go to visit a friend. S. followed the taxi, pulled the applicant out and began dragging her towards his car. The applicant sprayed tear gas in his face, whereupon he pushed her several times, took her bag and drove off with it. The applicant lodged a complaint with the police, concerning the attack and the theft of her bag which had contained identity documents and two mobile phones. S. then arrived at the police station and returned the bag to the applicant. The next day he brought the phones to the police, who returned them to the applicant, and the latter found her identity documents in her mailbox. In April 2018 the police decided not to open an investigation into the alleged theft as the property had been returned. It was also decided that proceedings should not be instigated concerning the threats, on the basis that neither the statements made by S. nor his actions constituted sufficient evidence that the death threats had been real. In August 2018 the applicant legally changed her name in order to prevent S. from being able to locate her. 
Under Chapter 16 of the Russian Criminal Code, there are three levels of assault occasioning actual bodily harm. 'Grievous bodily harm', as found in article 111, may involve the loss of a body part or the termination of pregnancy; 'medium bodily harm', as found in article 112, is bodily harm which leads to a long-term health disorder or loss of the ability to work; while 'minor bodily harm', as found in article 115, encompasses injuries which take up to three weeks to heal. Although causing grievous or medium bodily harm is subject to public prosecution, the offence of 'minor bodily harm' is liable only to private prosecution. This means that it is up to the victim to identify the perpetrator, collect the necessary evidence, secure testimony from witnesses and bring charges before a court.

Assault which causes physical pain without resulting in actual bodily harm is regarded as 'battery' under article 116. Aggravated battery encompasses battery committed for racial, ethnic, social or disorderly motives, and is a criminal offence. However non-aggravated battery is not criminalised, and is an administrative offence only.

The applicant argued before the ECtHR that the Russian authorities had violated article 3 of the $\mathrm{EC} \mathrm{HR}^{4}$ due to their failure to protect her from repeated acts of domestic violence and to hold the perpetrator accountable. She asserted that the Russian authorities had failed to establish a legislative framework to address domestic violence, and had also failed to investigate and prosecute her ill-treatment under the existing criminal law provisions.

In addition, the applicant argued that the failure of the authorities to put in place specific measures to combat gender-based discrimination against women constituted a violation of article 14 of the ECHR, taken in conjunction with article $3 .{ }^{5}$ The applicant, referring to official statistics and to independent studies and research undertaken by gender-violence advocates, asserted that domestic violence was widespread in Russia and that women were disproportionately impacted.

4 Article 3 states that, 'No one shall be subjected to torture or to inhuman or degrading treatment or punishment.'

5 The relevant part of article 14 states that, 'The enjoyment of the rights and freedoms set forth in this Convention shall be secured without discrimination on any ground such as sex ....' 


\section{The Judgment of the ECtHR}

In its judgment, the ECtHR first considered whether the treatment which the applicant had suffered fell within the scope of article 3. In this respect the Court commented that,

Ill-treatment must attain a minimum level of severity if it is to fall within the scope of Article $3 \ldots$ Even in the absence of actual bodily harm or intense physical or mental suffering, treatment which humiliates or debases an individual, showing a lack of respect for or diminishing his or her human dignity, or which arouses feelings of fear, anguish or inferiority capable of breaking an individual's moral and physical resistance, may be characterised as degrading and also fall within the prohibition set forth in Article $3 .{ }^{6}$

The Court was clearly of the view that the physical violence which the applicant had suffered reached the level of severity required to come within the ambit of article 3. However, the ECtHR also emphasised the psychological aspects of the abuse which the applicant had endured, and commented that, 'The feelings of fear, anxiety and powerlessness that the applicant must have experienced in connection with (S.'s) controlling and coercive behaviour were sufficiently serious as to amount to inhuman treatment within the meaning of Article 3 of the Convention: ${ }^{7}$

Having established that the treatment in question reached a level so as to come within the ambit of article 3 , the next question for the Court was whether the state had fulfilled its obligations to protect the applicant from such treatment. The ECtHR was of the view that,

the Russian legal framework - which does not define domestic violence whether as a separate offence or an aggravating element of other offences and establishes a minimum threshold of gravity of injuries required for launching public prosecution - falls short of the requirements inherent in the State's positive obligation to establish and apply effectively a system punishing all forms of domestic violence and providing sufficient safeguards for victims. ${ }^{8}$

6 Volodina v. Russia, (n 1$)$ at para. 73.

7 Ibid. at para. 75 .

8 Ibid. at para. 85 . 
The Court emphasised that requiring injuries to be of a certain level of severity before a criminal investigation can be initiated provides inadequate protection to victims as some forms of domestic violence, such as coercive and controlling behaviour and psychological and financial abuse, do not involve physical injury. The ECtHR also stated that,

A private prosecution puts an excessive burden on the victim of domestic violence, shifting onto her the responsibility for collecting evidence capable of establishing the abuser's guilt to the criminal standard of proof ... the challenge becomes unsurmountable for a victim who is expected to collect evidence on her own while continuing to live under the same roof as the perpetrator, being financially dependent on him, and fearing reprisals on his part. ${ }^{9}$

The Court then considered whether the state had fulfilled its duty to adopt 'the reasonable measures that might have been expected in order to avert a real and immediate risk of ill-treatment of which the authorities knew or ought to have known. ${ }^{10}$ The ECtHR was of the view that due to the repeated complaints which the applicant had made to the police, the authorities ought to have been aware of the violence to which the applicant had been subjected and of the real and immediate risk that such violence could recur. The question therefore arose of whether the state had adopted reasonable measures to protect the applicant. The ECtHR pointed out that measures such as restraining orders or protection orders are not available in Russian law. The Court stated that the response of the authorities had been 'manifestly inadequate'll and that the state had failed in its duty to investigate the ill-treatment that the applicant had suffered. The ECtHR therefore concluded that there had been a violation of article 3 .

In respect of the alleged violation of article 14, the Court commented that, 'Substantive gender equality can only be achieved with a gender-sensitive interpretation and application of the Convention provisions that takes into account the factual inequalities between women and men and the way they impact women's lives.' ${ }^{12}$ The ECtHR held that the evidence submitted by the applicant, along with information from international and domestic sources, was sufficient to establish prima facie indications that in Russia domestic violence affects women disproportionately. However, the authorities had not adopted any legislation which was sufficient to provide protection to women

id. at para. 82 .

$10 \quad$ Ibid. at para. 77.

$11 \quad$ Ibid. at para. 91.

12 Ibid. at para. 111. 
who have been disproportionately affected by domestic violence. The ECtHR thus held that there had also been a violation of article 14, taken in conjunction with article 3 .

\section{Analysis of the Judgment}

The case of Volodina v. Russia constitutes a valuable addition to the jurisprudence of the ECtHR on domestic violence. It is a strong judgment which reinforces the positive obligations which states have to protect victims of this form of abuse. In this case the Court emphasised the important fact that domestic violence is not only constituted by physical violence, but can also consist of coercive control and psychological abuse, and indeed that such forms of non-physical abuse can come within the scope of article $3 .{ }^{13}$ The Court's statements concerning the need for prosecutions in domestic violence cases to be taken by the state, as opposed to the onus being placed on victims to bring private prosecutions, are also welcome.

The findings of the ECtHR cannot however be said to be surprising. The response of Russia to the issue of domestic violence has been the subject of criticism from the UN Committee on the Elimination of Discrimination against Women (the CEDAW Committee). For example in its Concluding Observations on the eighth periodic report of the Russian Federation, the CEDAW Committee expressed its concern that 'cases of violence against women are underreported, given that they are considered a private matter, and that victim protection services, such as crisis centres and shelters, are insufficient.'14 The Committee urged the state, 'To adopt comprehensive legislation to prevent and address violence against women, including domestic violence, introduce ex officio prosecution of domestic and sexual violence and ensure that women and girls who are victims of violence have access to immediate means of redress and protection and that perpetrators are prosecuted and adequately punished' ${ }^{15}$ Likewise, in O.G. v. the Russian

13 For discussion of the concept of coercive control, see V Bettinson and C Bishop, 'Is the Creation of a Discrete Offence of Coercive Control Necessary to Combat Domestic Violence?' (2015) 66 Northern Ireland Legal Quarterly 179-197; E Stark, 'Rethinking Coercive Control' (2009) 15 Violence Against Women 1509-1525; E Williamson, 'Living in the World of the Domestic Violence Perpetrator: Negotiating the Unreality of Coercive Control' (2010) 16 Violence Against Women 1412-1423.

14 Committee on the Elimination of Discrimination against Women, Concluding observations on the eighth periodic report of the Russian Federation, 20 November 2015, CEDAW/ C/RUs/Co/8, at para. 21 .

Ibid. at para. 22(a). 
Federation, ${ }^{16}$ a complaint made under the individual communications procedure found in the Optional Protocol to the UN Convention on the Elimination of All Forms of Discrimination against Women 1979 (CEDAW), the CEDAW Committee stated that Ms O.G. 'was subjected to fear and anguish when she was left without State protection while she was periodically persecuted by her aggressor and was exposed to renewed trauma when the State organs that ought to have been her protector, in particular the police, instead refused to offer her protection and denied her status as a victim.' ${ }^{17}$ In addition, at the time of writing the Russian Federation is one of only two states within the Council of Europe which have neither ratified nor signed the Council of Europe Convention on the Preventing and Combating of Violence Against Women and Domestic Violence 2011 (the Istanbul Convention). ${ }^{18}$ Given the criticism which the response of Russia to the issue of domestic violence has previously received, it would be surprising if the ECtHR had not found violations of the ECHR in Volodina.

However, the case of Volodina v. Russia again raises questions regarding how domestic violence is conceptualised by the ECtHR. In a separate opinion issued by Judge Pinto De Albuquerque, the Judge expressed his view that, although a violation of article 3 was found in the case, it should have been held that the ill-treatment suffered by the applicant went beyond inhuman and degrading treatment and reached the threshold for torture. In Ireland $v$. United Kingdom, the Court stated that torture consists of 'deliberate inhuman treatment causing very serious and cruel suffering.' ${ }^{19}$ In the view of Judge Pinto De Albuquerque, this threshold was met in the instant case. As the Judge stated, the applicant,

was subjected to multiple and persistent instances of extreme domestic violence, including a punch to her stomach, which in fact led to medical advice that she should induce the abortion of her unborn baby. She was further psychologically taunted through the publication of private photographs, the finding of what was believed to be a GPS tracker inside her purse, threats to kill her - which S. attempted to substantiate by damaging her car - and abduction from her city of residence. ${ }^{20}$

16 Communication no. 91/2015, 6 November 2017.

17 Ibid. at para. 7.9.

18 The other state which has neither ratified nor signed the Istanbul Convention at the time of writing is Azerbaijan.

19 (1978) 2 EHRR 25, at para. 167.

20 Volodina v. Russia, supra $\mathrm{n} 1$ at para. 7 of Separate Opinion of Judge Pinto De Albuquerque, Joined by Judge Dedov. 
In support of his view, Judge Pinto De Albuqerque cited General Comment 2 of the UN Committee against Torture, which asserts that a state's systematic acquiescence to privately inflicted harm raises concerns under the UN Convention against Torture and other Cruel, Inhuman or Degrading Treatment or Punishment $1984 .{ }^{21}$ Indeed the Committee against Torture included violence against women as a principal area of concern in its Concluding Observations on the sixth periodic report submitted by the Russian Federation. The Committee expressed its concern at 'the absence of a definition of domestic violence in the State party's legislation' and at 'reports that police officers are often unwilling to register complaints of domestic violence and even discourage victims from submitting them, and that victims continue to be compelled to participate in reconciliation processes with the perpetrators. ${ }^{22}$

It does seem that the argument of Judge Pinto De Albuquerque has much to commend it. As the Judge asserted, 'When severe forms of pain and suffering are deliberately inflicted on a person, this must be identified as torture. ${ }^{23}$ In the majority judgment in Volodina, the ECtHR referred to the need to adopt a 'gender-sensitive approach' when applying the ECHR to cases involving issues such as domestic violence. ${ }^{24}$ It is certainly arguable that the adoption of such an approach should involve the recognition of 'the gravity and effect of persisting patterns of domestic violence. ${ }^{25}$ As Judge Pinto De Albuquerque commented, 'If the State faces condemnation for allowing its women to be submitted to torture, the positive obligation to protect is even more stringent.'26

Issues have arisen concerning previous case law of the ECtHR in terms of how domestic violence is conceptualised by the Court. In cases on this issue, applicants have usually sought to make arguments based upon articles 3 and $8^{27}$ and also, in some instances, articles $2^{28}$ and 14 of the ECHR. However, up until 2013 the approach taken by the ECtHR as regards on which articles it based its findings of breaches of the ECHR in domestic violence cases was somewhat incoherent, particularly in terms of the use of articles 3 and 8. In certain cases para. 18.

Committee against Torture, General Comment No. 2, 24 January 2008, CAT/C/GC/2, at Committee against Torture, Concluding observations on the sixth periodic report of the Russian Federation, 28 August 2018, CAT/C/RUs/Co/6, at para. 3 o.

Volodina v. Russia, (n 1 ) at para. 8 of Separate Opinion of Judge Pinto De Albuquerque, Joined by Judge Dedov.

Ibid. at para 111.

Ibid. at para. 8 of Separate Opinion of Judge Pinto De Albuquerque, Joined by Judge Dedov. Ibid. at para. 9 .

Article 8(1) states that, 'Everyone has the right to respect for his private and family life, his home and his correspondence.'

Article 2(1) states that, 'Everyone's right to life shall be protected by law.' 
such as Opuzv. Turkey ${ }^{29}$ and E.S. and Others v. Slovakia, ${ }^{30}$ the ECtHR found violations of article 3. However in other cases such as Bevacqua and $S v$. Bulgaria, ${ }^{31}$ $A$ v. Croatia ${ }^{32}$ and Kalucza v. Hungary ${ }^{33}$ the Court found breaches of article 8 and then stated that it was thus unnecessary to examine the cases under article 3 also. Far from the question arising of under which limb of article 3 domestic violence should be categorised, the Court seemed to take the view in its early jurisprudence on domestic abuse that if it decided that a violation of the ECHR should be found, it did not matter to any great extent on which specific article this finding was held to be based.

One explanation of the greater use of article 8 , as opposed to article 3 , in the Court's earlier case law on domestic violence could of course be that the Court had not yet fully realised the seriousness of this issue. However this explanation does not seem adequate, given that the Court did find violations of article 3 in some relatively early cases involving domestic violence. A more likely explanation lies in the fact that for reasons of efficiency and practicality, the Court frequently adopts the approach of finding a breach of one article of the ECHR and then omitting to consider the application of other articles on which arguments have been made by applicants. This approach is by no means limited to cases of domestic violence. It is likely that the Court's apparent preference for the use of article 8 as opposed to article 3 in its earlier jurisprudence on this issue was due simply to the fact that it can be more straightforward to establish a violation of article 8 than it is to establish a breach of article 3 .

However, the problem with an approach based on practicality is that it can be mistaken for an approach founded on principle, and indeed such difficulties emerged relatively quickly. In the 2013 case of Valiuliene $v$. Lithuania, ${ }^{34}$ the state argued that the ill-treatment to which the applicant, a victim of domestic violence, had been subjected had not been sufficiently severe to fall within the ambit of article 3. As the applicant had sustained minor bodily harm which had not resulted in short or long term health problems, according to the state 'it could be said that the injuries sustained by the applicant had been of a merely trivial nature. ${ }^{35}$ The state did however acknowledge that 'it was regrettable that the case had not been fully and efficiently investigated and the

\footnotetext{
29 Supran 3.

30 Ibid.

31 Ibid.

32 Ibid.

33 Ibid.

34 Ibid.

35 Ibid. at para. 55 .
} 
perpetrator of the alleged crime had not been convicted. ${ }^{36}$ The state therefore presented the ECtHR with a unilateral declaration acknowledging a breach of article 8 . The Court however refused to accept this declaration, found a violation of article 3 and stated that it was not necessary to examine the complaint under article 8 , as a breach of article 3 had already been found.

Indeed it was not only the state which seemed to take the view that cases of domestic violence were more appropriately considered under article 8 , rather then article 3. One of the Court's own judges, Judge Jociene, entered a Dissenting Opinion in Valiuliene in which he asserted that 'the Court has incorrectly relied on Article 3 in the circumstances of the present case' and that, 'This position of the Chamber is not supported by the Court's case-law, where domestic violence cases are mostly examined from the perspective of Article 8.37 Judge Jociene proceeded to comment that, 'Accordingly ... the applicant's complaint ... should have been examined under Article 8., ${ }^{38}$

It is true that there seems to be nothing to distinguish the violence suffered by the applicant in Valiuliene as regards level of intensity or severity of injuries sustained from that experienced by the applicants in other cases involving domestic violence in which the ECtHR had found violations of article 8 and omitted to consider article $3{ }^{39}$ Interestingly, there is no explanation for this difference in approach in the judgment in Valiuliene, however if the Court had accepted the state's unilateral declaration of a violation of article 8 it would in essence have been accepting that there had been no violation of article 3 in this case, and it appears that such an outcome was not desired by the ECtHR. It seems that the case of Valiuliene served to highlight to the ECtHR that the important issue in domestic violence cases is not only whether a violation of the ECHR should be found, but also on which provision of the Convention such a finding should be based. Indeed this case marked a change in the approach of the ECtHR and henceforth article 3 was used much more extensively in cases involving domestic violence. ${ }^{40}$

$36 \quad$ Ibid. at para. 61.

37 Ibid, at para. 10 of Dissenting Judgment of Judge Jociene.

38 Ibid, at para.

39 For further discussion of this point and of Valiuliene more generally, see R McQuigg, 'The European Court of Human Rights and Domestic Violence: Valiuliene v Lithuania' (2014) 18 International Journal of Human Rights $75^{6-773}$.

40 For example, violations of article 3 have been found in Eremia and Others v. Republic of Moldova, (n 3); B. v the Republic of Moldova, (n 3); Mudric v. Republic of Moldova, (n 3); N.A. v. Republic of Moldova, (n 3); T.M. and C.M.v. Republic of Moldova, (n 3); M.G. v. Turkey, (n 3); Balsan v. Romania, (n 3); and Talpis v. Italy, (n 3). 
The fact that in Volodina the ECtHR emphasised that the psychological abuse suffered by victims of domestic violence is sufficient to meet the necessary threshold of severity to engage article 3 even in the absence of physical injury is praiseworthy, and is reflective of the evolution which the Court's jurisprudence on this issue has undergone. Such statements on the part of the ECtHR are a very long way from the understanding of the Court's approach which was held by the state in Valiuliene. There is certainly no longer any scope for a state to believe that a violation of article 3 will not be found due to an applicant's physical injuries being insufficiently severe.

Likewise, the issue which arose in Volodina regarding whether domestic violence should be recognised as torture, as opposed to inhuman or degrading treatment, is also illustrative of the evolution of the case law of the ECtHR. It is now beyond doubt that cases of domestic violence will usually fall within the scope of article 3; rather the question has become whether domestic violence should be expressly held to come within the 'torture' limb of this provision. It is certainly arguable that this would be a very welcome development, as it would make a strong statement concerning the seriousness of this issue. Indeed a number of commentators have likened domestic violence to torture. ${ }^{41}$ It is notable that in certain cases, such as Ireland $v$ United Kingdom, ${ }^{42}$ a state has attempted (albeit unsuccessfully) to admit to inhuman and degrading treatment in the hope that the ECtHR will not then consider whether the ill-treatment in question actually reached the threshold of constituting torture. It is possible that a state could attempt to make such an argument in a case involving domestic violence, thus prompting the ECtHR to make a definitive ruling on this issue, much in the same way that the state's unilateral declaration in Valiuliene prompted a change in approach on the part of the Court as regards the use of article 3 in domestic violence cases.

In conclusion therefore, Volodina $v$. Russia is a valuable addition to the case law of the ECtHR on domestic violence in that it reinforces again the positive

41 For example, R Copelon, 'Intimate Terror: Understanding Domestic Violence as Torture', in R Cook (ed), Human Rights of Women - National and International Perspectives, (University of Pennsylvania Press, 1994); E Grdinic, 'Application of the Elements of Torture and Other Forms of Ill-Treatment, as Defined by the European Court and Commission of Human Rights, to the Incidents of Domestic Violence' (2000) 23 Hastings International and Comparative Law Review 217-26o. 
obligations placed upon states to protect victims. The Court demonstrated a clear awareness that domestic violence is not only constituted by physical violence, and that coercive control and psychological abuse can come within the ambit of article 3. However, the case of Volodina also serves to illustrate the way in which the jurisprudence of the ECtHR on this issue has evolved, from a reliance primarily on article 8 to a situation whereby the use of article 3 is commonplace and the debate has become whether domestic violence should be expressly conceptualised by the Court as torture. It seems that such a finding could well constitute the next development in the case law of the ECtHR on this issue. 